\title{
Platelet-activating Factor-mediated Transmembrane Signaling in Human B Lymphocytes Is Regulated through a Pertussis- and Cholera Toxin-sensitive Pathway
}

\author{
Bruce D. Mazer, Hiroyasu Sawami, Attila Tordai, and Erwin W. Gelfand \\ Division of Basic Sciences, Department of Pediatrics, National Jewish Center for Immunology and Respiratory Medicine, \\ and the Raymond and Beverly Sackler Foundation, Denver, Colorado 80206
}

\begin{abstract}
Platelet-activating factor (PAF) stimulates human B cells, resulting in elevation of intracellular calcium and the release of inositol phosphates. This signaling pathway is inhibited in the presence of pertussis (PT) or cholera toxin (CT). Preincubation of human $B$ cells with either toxin, but not their inactive subunits, for $3 \mathrm{~h}$ blocked these PAF-induced responses in two B-lymphoblastoid cell lines. This effect was time dependent, with some inhibition noted at $\mathbf{3 0} \mathrm{min}$, but only after preincubation for 2-3 h was maximum inhibition achieved. This inhibitory activity was also dose dependent. The toxins blocked both PAF-induced transmembrane uptake of $\mathrm{Ca}^{2+}$ as well as release of $\mathrm{Ca}^{2+}$ from internal stores, and were selective in that activation events after cross-linking of surface IgM were not affected. Further, the toxins did not appear to act through elevation of intracellular levels of cAMP. These data, coupled with previous observations on the absence of heterologous desensitization between PAF and sIgM receptors, may delineate distinct signaling pathways in human $B$ cells. This may reflect different roles for GTP-binding proteins in the activation of human B cells. ( J. Clin. Invest. 1992. 90:759-765.) Key words: B lymphocytes $\bullet$ platelet-activating factor $\bullet$ guanosine triphosphatebinding proteins $\bullet$ signal transduction
\end{abstract}

\section{Introduction}

Platelet-activating factor (PAF) ${ }^{1}$ is an ether-linked phospholipid that can modulate vascular, muscular, and immune function. It is commonly thought to act via a specific receptor, although to date this has been inferred from indirect measures such as radiolabeled PAF binding or by the inhibitory effects of specific receptor antagonists ( 1 ). There also appears to be multiple signaling pathways that are activated after the interaction of PAF with its specific receptor.

Address correspondence to Dr. Erwin W. Gelfand, National Jewish Center for Immunology and Respiratory Medicine, 1400 Jackson Street, Denver, CO 80206. 1992

Received for publication 24 July 1991 and in revised form 31 March

1. Abbreviations used in this paper: $\left[\mathrm{Ca}^{2+}\right]_{\mathrm{i}}$, free intracellular calcium; CT, cholera toxin; IP, inositol; IP $_{1}$, IP monophosphate; IP $_{2}$, IP bisphosphate; $\mathrm{IP}_{3}$, IP trisphosphate; $\mathrm{IP}_{4}$, IP tetraphosphate; PAF, plateletactivating factor; $\mathrm{PIP}_{2}$, phosphatidylinositol bisphosphate; PLC, phospholipase C; PT, pertussis toxin.

J. Clin. Invest.

(C) The American Society for Clinical Investigation, Inc.

0021-9738/92/09/0759/07 \$2.00

Volume 90, September 1992, 759-765
Cell activation after PAF binding has been demonstrated to be mediated via activation of a GTP-binding protein in human and rabbit polymorphonuclear leukocytes $(2,3)$ and rabbit and human platelets $(4,5)$. The specificity of these $G$ proteins, as defined by pertussis (PT) and cholera (CT) toxin sensitivity, differs between PMNs and platelets (5). PAF-induced hydrolysis of GTP (GTPase activity) in human neutrophils is completely inhibited by PT and CT, while the same biochemical reaction in human platelets is insensitive to PT and CT (5). This unique profile has led Hwang $(1,5)$ to postulate the existence of at least two different classes of PAF receptors in human cells, each triggering a specific pathway for signaling.

Recently we reported that interaction of PAF with its receptor causes an increase in intracellular levels of calcium, liberation of inositol phosphates, and expression of early oncogenes in a number of B-lymphoblastoid cell lines (6). These actions are completely blocked by PAF receptor antagonists (6). PAF appears to be a unique ligand for these lymphocytes since it triggers a very rapid $\mathrm{Ca}^{2+}$ response when compared to the response of sIgM cross-linking (6). Further, PAF is not responsible for heterologous desensitization of the response to crosslinking surface IgM receptors (6). A potential explanation for the difference in signaling pathways between the PAF and sIgM receptors in B lymphocytes is suggested by their respective sensitivity to PT and CT. Although some B-lymphoblastoid cell lines will mobilize $\mathrm{Ca}^{2+}$ and hydrolyze phosphatidylinositol bisphosphate $\left(\mathrm{PIP}_{2}\right)$ when stimulated by anti-IgM antibody $(7$, 8 ), anti-IgM-mediated $\mathrm{PIP}_{2}$ hydrolysis cannot be blocked by PT or CT (9).

In view of the potential differences between PAF- and antiIgM-mediated cell activation, we have attempted to define the signaling pathway that PAF initiates upon interaction with its specific receptor. The data suggest that the increase in intracellular $\mathrm{Ca}^{2+}$ levels elicited by PAF is via a PT- and CT-sensitive pathway that is not influenced by elevated cAMP levels. The data confirm that PAF-induced hydrolysis of $\mathrm{PIP}_{2}$ and generation of inositol phosphates is regulated through the same pathway. This pattern is similar to human polymorphonuclear leukocytes (5). We also demonstrate that the signaling pathway for anti-IgM is different from that of PAF in that it is sensitive neither to the toxins nor to elevated cAMP. This may explain the lack of heterologous desensitization between these two ligands.

\section{Methods}

Cell lines. The B-lymphoblastoid cell lines used in this series of experiments included the $\mathrm{HSCE}^{-}$cell line, an IgG-secreting EBV-transformed B-cell line, and LA350, an sIgM-secreting and IgM-expressing EBV-transformed B-cell line (kindly provided by Drs. W. Shearer and H. Rosenblatt, Texas Children's Hospital, Houston, TX) (8). Both 
lines were maintained in culture in RPMI 1640 (Gibco Laboratories, Grand Island, NY) supplemented with 10\% FCS (HyClone Laboratories, Logan, UT) and $50 \mathrm{U} / \mathrm{ml}$ penicillin, $50 \mathrm{ng} / \mathrm{ml}$ streptomycin, 10 $\mu \mathrm{g} / \mathrm{ml} \mathrm{L}$-glutamine, and $5 \mu \mathrm{g} / \mathrm{ml}$ sodium pyruvate, all purchased from Gibco Laboratories. Passages were performed biweekly and new cultures were established from frozen stock approximately every $8 \mathrm{wk}$.

Ligands. Platelet activating factor (C-16), enantio-PAF, and lysoPAF were purchased from Biomol Research Laboratories, Inc. (Plymouth Meeting, PA). These were reconstituted in ethanol and stored at $-20^{\circ} \mathrm{C}$ until use. Aliquots of PAF or its analogues were freshly prepared for each experiment by drying down the lipid under a stream of nitrogen and resuspension in PBS containing $0.125 \%$ BSA by sonification. Pertussis and cholera toxins were purchased from Calbiochem Corp. (San Diego, CA). The B-oligomer of pertussis toxin and the B-subunit of cholera toxin were also obtained from Calbiochem Corp. These compounds were reconstituted with distilled water according to the manufacturers' instructions, and stored at $4^{\circ} \mathrm{C}$ until use. Forskolin was purchased from Calbiochem Corp. and 8-bromo cAMP and theophylline were purchased from Sigma Chemical Co. (St. Louis, MO). Anti-IgM ([Fab' $\left.]_{2}\right)$ was purchased from Tago, Inc. (Burlingame, CA).

Medium. Serum-free medium with supplemental transferrin was prepared as described previously (10). We have demonstrated that cell viability and immunoglobulin synthesis were equivalent in this medium compared to FCS-containing medium; however, the serum-free medium contains no acetylhydrolase activity, allowing for optimal activity and control of PAF in vitro (10).

Measurement of intracellular calcium levels. Changes in free intracellular calcium levels $\left(\left[\mathrm{Ca}^{2+}\right]_{i}\right)$ were measured as previously described (6). Cells were resuspended in serum-free medium at a concentration of $1 \times 10^{7} / \mathrm{ml}$. They were then incubated with $1 \mu \mathrm{M}$ of indo-1-AM (Calbiochem Corp.) at $37^{\circ} \mathrm{C}$ for $30 \mathrm{~min}$. Cells were then washed and resuspended at a concentration of $4 \times 10^{6} / \mathrm{ml}$ in serum-free medium and allowed to equilibrate at $37^{\circ} \mathrm{C}$ for at least $30 \mathrm{~min}$. $1-\mathrm{ml}$ aliquots of indo-1-AM-loaded cells were spun to pellet and resuspended in $2 \mathrm{ml}$ of a buffer solution containing $2 \mathrm{mM}$ Hepes, $140 \mathrm{mM} \mathrm{NaCl}, 2 \mathrm{mM} \mathrm{KCl}$, $10 \mathrm{mM}$ glucose, $1 \mathrm{mM} \mathrm{MgCl}$, and $1 \mathrm{mM} \mathrm{CaCl}_{2}$. For experiments in $\mathrm{Ca}^{2+}$-free medium, no $\mathrm{Ca}^{2+}$ was added and $0.5 \mathrm{mM}$ EGTA was included in the medium. Cells were suspended in the $\mathrm{Ca}^{2+}$-free medium for 5-10 min before addition of the ligand. Cytoplasmic $\mathrm{Ca}^{2+}$ was monitored, calibrated, and calculated using a spectrofluorimeter (F4010; Hitachi Scientific Instruments, San Jose, CA) as described (11).

Analysis of inositol phosphate liberation. Cells were washed twice in PBS and suspended $\left(5 \times 10^{6} / \mathrm{ml}\right)$ in DME supplemented with 100 $\mathrm{U} / \mathrm{ml}$ penicillin, $100 \mu \mathrm{g} / \mathrm{ml}$ streptomycin, $2 \mathrm{mM}$ L-glutamine, 100 $\mu \mathrm{g} / \mathrm{ml}$ sodium pyruvate, and $0.25 \%$ BSA to which was added $1 \mu \mathrm{Ci} / \mathrm{ml}$ $\left[{ }^{3} \mathrm{H}\right]$ myoinositol (12). After $20-22 \mathrm{~h}$ of incubation at $37^{\circ} \mathrm{C}$, the cells were washed twice in the medium and incubated with $20 \mu \mathrm{M} \mathrm{LiCl}$ for $15 \mathrm{~min}$. Cells were then centrifuged and resuspended in medium with $20 \mu \mathrm{M} \mathrm{LiCl}$. Aliquots $(500 \mu \mathrm{l})$ of the cell suspension were then incubated with $\operatorname{PAF}\left(10^{-7} \mathrm{M}\right)$ or the suspension vehicle at $37^{\circ} \mathrm{C}$. At varying times $1.5 \mathrm{ml} \mathrm{CHCl}_{3}: \mathrm{CH}_{3} \mathrm{OH}(1: 2)$ were added to stop the reaction. The lipids were extracted by addition of $0.5 \mathrm{ml}$ chloroform and $0.5 \mathrm{ml}$ $\mathrm{dH}_{2} \mathrm{O}$. The upper aqueous phase was collected, $\mathrm{pH}$ adjusted to 7.2, and stored at $4^{\circ} \mathrm{C}$ until use. The total aqueous phase was applied to $0.6 \mathrm{ml}$ columns of Dowex AG1-X8 (200-400 mesh; Bio-Rad Laboratories, Richmond, CA) in the formate form. The columns were washed with $20 \mathrm{ml}$ of water to remove inositol and neutralize $\mathrm{HCl}$. Glycero-phosphoinositol was eluted with $20 \mathrm{ml}$ of $2.5 \mathrm{mM}$ sodium tetraborate plus $60 \mathrm{mM}$ sodium formate. Inositol monophosphate $\left(\mathrm{IP}_{1}\right)$, inositol bisphosphate $\left(\mathrm{IP}_{2}\right)$, inositol trisphosphate $\left(\mathrm{IP}_{3}\right)$, and a small percentage of inositol tetraphosphate $\left(\mathrm{IP}_{4}\right)$ were separated by stepwise elution with $20 \mathrm{ml}$ of $0.1,0.25$, and $1 \mathrm{M}$ ammonium formate in $0.1 \mathrm{M}$ formic acid. 2 - $\mathrm{ml}$ fractions were collected and incorporation of $\left[{ }^{3} \mathrm{H}\right]$ inositol determined.

\section{Results}

$P A F$-induced increases in intracellular calcium are attenuated by $P T$ and $C T$. We have demonstrated previously that PAF induces a rapid increase in intracellular $\mathrm{Ca}^{2+}$ in $\mathrm{B}$-lymphoblastoid cell lines which is composed of a transient peak and a sustained plateau (6). As with other ligands (13), the initial, transient response appears to result primarily from the release of intracellular $\mathrm{Ca}^{2+}$ stores, and the plateau reflects transmembrane $\mathrm{Ca}^{2+}$ uptake. The elevation of $\left[\mathrm{Ca}^{2+}\right]_{i}$ is a result of the interaction of PAF with its specific receptor, as PAF analogues

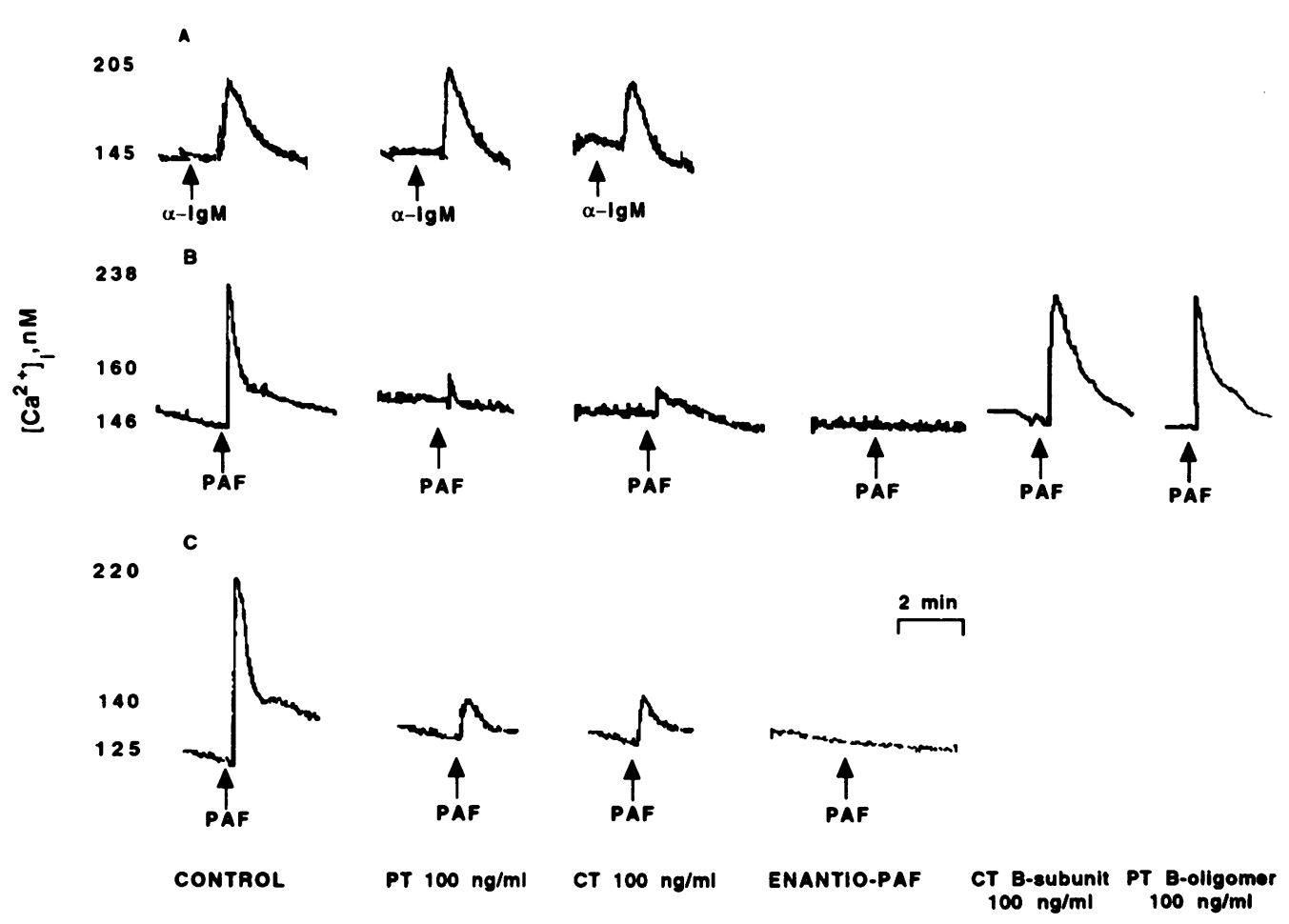

Figure 1. PT and CT inhibit the elevation of $\left[\mathrm{Ca}^{2+}\right]_{i}$ induced by PAF but not antiIgM antibody. LA350 or $\mathrm{HSCE}^{-}$cells were incubated with either PT ( $100 \mathrm{ng} / \mathrm{ml})$ or CT $(100 \mathrm{ng} / \mathrm{ml})$ for $3 \mathrm{~h}$, washed, and loaded with indo-1-AM as described. They were then stimulated with PAF $\left(10^{-7} \mathrm{M}\right)$ or enantio-PAF $\left(10^{-7} \mathrm{M}\right)$, as indicated. LA350 cells were also preincubated with B-oligomer of PT $(100 \mathrm{ng} / \mathrm{ml})$ or B-subunit of CT $(100 \mathrm{ng} / \mathrm{ml})$ for $3 \mathrm{~h}$ before stimulation with PAF. The LA350 line only was stimulated with anti-IgM antibody ( $20 \mu \mathrm{g} /$ $\mathrm{ml}$ ) in the same experiments. $(A)$ LA350 stimulated by anti-IgM; $(B)$ LA350 stimulated by PAF; $(C) \mathrm{HSCE}^{-}$ cells stimulated by PAF. The figure demonstrates representative tracings from eight separate experiments. 

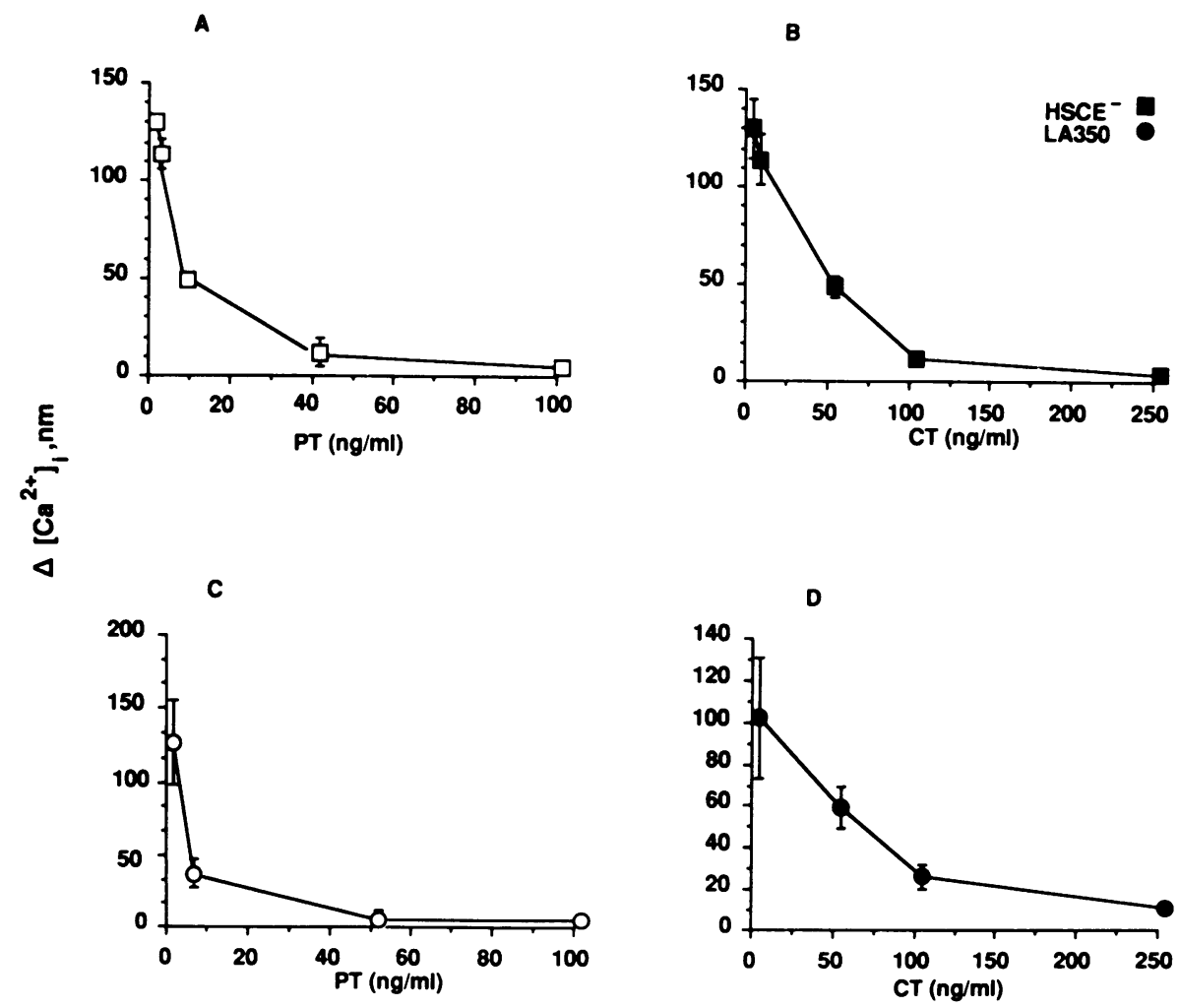

Figure 2. Dose-dependent inhibition of PAF-induced elevations of $\left[\mathrm{Ca}^{2+}\right]_{i}$ by PT and CT. B-cell lines were incubated for 3 $h$ with various concentrations of PT $(\square, 0)$ or CT $(\square, \bullet)$, then loaded with indo-1-AM and PAF-stimulated changes in $\left[\mathrm{Ca}^{2+}\right]_{\mathrm{i}}$ $\left(\Delta\left[\mathrm{Ca}^{2+}\right]_{\mathrm{i}}\right)$ above resting baseline values were calculated. $(A)$ and $(B) \mathrm{HSCE}-;(C)$ and $(D)$ LA350. The figure demonstrates means \pm SEM of four separate experiments.

such as lyso-PAF (6) and enantio-PAF (Fig. 1, $B$ and $C$ ) do not cause an elevation of $\left[\mathrm{Ca}^{2+}\right]_{i}$, and the action is blocked by specific PAF antagonists (6). To examine if inhibition of PAFinduced signaling could be achieved with PT or CT, the cell lines $\mathrm{HSCE}^{-}$or LA350 were incubated for $3 \mathrm{~h}$ with $100 \mathrm{ng} / \mathrm{ml}$ of either PT or CT. A marked inhibition of the calcium response was observed after addition of $10^{-7} \mathrm{M}$ PAF to PT- or CT-treated B-lymphoblastoid cells, compared to control (Fig. 1). The inhibition at the dose of $100 \mathrm{ng} / \mathrm{ml}$ appeared to be equally effective in blocking both the transient peak of the biphasic calcium curve and the plateau response. At concentrations of $100 \mathrm{ng} / \mathrm{ml}$, neither the B-oligomer of PT nor the B-subunit of CT affected the $\mathrm{Ca}^{2+}$ response in LA350 cells triggered by PAF (Fig. 1).

Fig. 1 also indicates the contrast between PAF and anti-IgM stimulation after PT or CT preincubation. Transmembrane signaling via the sIgM receptor leading to elevations in $\left[\mathrm{Ca}^{2+}\right]_{i}$ has not been influenced by CT in either human (14) or murine B-cell lines (15). Indeed, we found that after a 3-h incubation with PT or CT and anti-IgM stimulation of the LA350 line (Fig. 1), there was no variation in the $\mathrm{Ca}^{2+}$ response compared to control. Similarly the B-subunits of the toxins were inactive (data not shown). The PAF response was markedly diminished under the same conditions.

The inhibitory effect of the toxins on the PAF-induced increases in $\left[\mathrm{Ca}^{2+}\right]_{i}$ was dose dependent. After a 3-h incubation with various concentrations of PT or CT, the $\mathrm{IC}_{50}$ of PT was $8 \pm 5 \mathrm{ng} / \mathrm{ml}$ (Fig. 2, $A$ and $C$ ) while the $\mathrm{IC}_{50}$ for CT was found to be $40 \pm 8 \mathrm{ng} / \mathrm{ml}$ (Fig. $2, B$ and $D$ ).

The effect of the toxins was also time-dependent. A $10 \%$ change in elevation of $\left[\mathrm{Ca}^{2+}\right]_{\mathrm{i}}$ was obtained after a $30-\mathrm{min}$ preincubation (data not shown). The maximal effect was noted after preincubation of the cells for $>2 \mathrm{~h}$, with a 3-h preincubation providing the most consistent results. No effect of the toxins was observed after a 5- or 15-min preincubation. 3-h preincubations with PT or CT with the B-cell lines did not change baseline $\left[\mathrm{Ca}^{2+}\right]_{\mathrm{i}}$ detected by $>10 \%$. Also, to ensure that the effects of the toxins were not due to any immediate effects on B-cell activation as has been described by Rogers et al. in T lymphocytes (16), PT or CT were added to the B-lymphoblastoid cells directly in the spectrofluorimeter cuvette after indo-1 AM loading. No elevations in the level of $\left[\mathrm{Ca}^{2+}\right]_{i}$ were detected immediately after addition of either toxin.

To define further the effect of the toxins on the individual components of the calcium response, approximate $\mathrm{IC}_{50}$ doses of PT $(5 \mathrm{ng} / \mathrm{ml})$ and CT $(50 \mathrm{ng} / \mathrm{ml})$ were used in order to avoid the $>90 \%$ inhibition achieved with higher concentrations of the toxins. Experiments were performed using indo-1loaded B-lymphoblastoid cells suspended in $\mathrm{Ca}^{2+}$-free medium. The cells were stimulated with PAF, which caused a rapid but transient increase in $\left[\mathrm{Ca}^{2+}\right]_{\mathrm{i}}($ Fig. $3 A) .1 \mathrm{mM}$ of $\mathrm{Ca}^{2+}$ was then added, leading to an increase in $\left[\mathrm{Ca}^{2+}\right]_{\mathrm{i}}$ and a more sustained plateau representing transmembrane uptake. After incubation with $5 \mathrm{ng} / \mathrm{ml}$ of PT (Fig. $3 B$ ) or $50 \mathrm{ng} / \mathrm{ml}$ of CT (Fig. $3 C$ ), both the transient peak and the plateau phase responses were blunted. This implies that blocking of GTP-binding protein activation by the toxins influences both the liberation of $\mathrm{Ca}^{2+}$ from internal stores, and transmembrane $\mathrm{Ca}^{2+}$ uptake, presumably through ligand-gated calcium channels. At these lower concentrations of the toxins, a more prominent action on $\mathrm{Ca}^{2+}$ uptake than release from internal stores was observed.

Effect of CT and PT on PAF-induced phosphatidylinositol phosphate metabolism. After receptor ligand interaction, $\mathrm{PIP}_{2}$ hydrolysis results from the activation of phospholipase $\mathrm{C}$ (PLC), an event linked to GTP-binding protein activation 


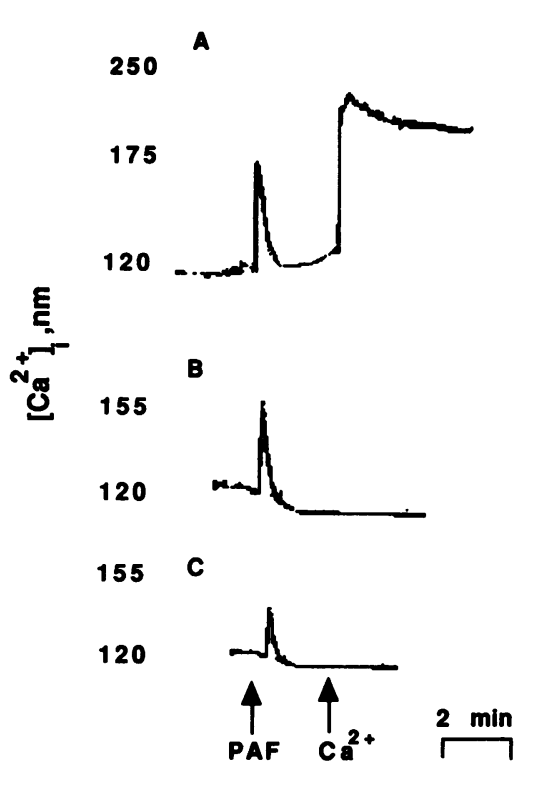

(17). PAF has been suggested to be a potent activator of PLC in many cell systems $(18,19)$ including B lymphocytes $(6)$, inasmuch as $\mathrm{PIP}_{2}$ breakdown products $\mathrm{IP}_{3}, \mathrm{IP}_{2}$, and $\mathrm{IP}_{1}$ accumulate rapidly after PAF stimulation of cells. After the incubation of $\mathrm{HSCE}^{-}$(Fig. 4) or LA350 cells (data not shown) with PT or CT, PAF stimulation generated a minimal liberation of inositol phosphates. Again, PT and CT did not stimulate IP liberation on their own (data not shown).

Inhibition of the PAF response is not due to elevated cAMP. It is well documented that after binding of CT to the $\alpha_{s}$ subunit of G-protein complexes, intracellular cAMP levels are elevated (20). In some B-cell systems, increased levels of cAMP have been demonstrated to diminish cellular responsiveness to ligand-induced elevations of $\left[\mathrm{Ca}^{2+}\right]_{i}$ after anti-Ig stimulation $(21,22)$. HSCE $^{-}$cells (Fig. 5) and LA350 cells (Fig. 6) were preincubated for $30 \mathrm{~min}$ with various doses of forskolin $\left(10^{-3}\right.$ $\left.10^{-4} \mathrm{M}\right)$ or the cAMP analogue 8-bromo-cAMP $\left(10^{-4} \mathrm{M}\right)$ alone or in combination with $100 \mu \mathrm{M}$ theophylline. Under these conditions the protein kinase A activity ratio (23) increased from four- to sixfold with 8-bromo-cAMP and forskolin, respectively, when compared to controls, and these increases were sustained over the course of the experiment. Neither of these treatments had an effect on the PAF-induced increases in $\left[\mathrm{Ca}^{2+}\right]_{i}$ (Fig. 5) or on the $\mathrm{Ca}^{2+}$ response induced by anti-IgM (Fig. 6). In additional studies (data not shown), cells were preincubated with 8-bromo-cAMP $\left(10^{-4} \mathrm{M}\right)$ and $100 \mu \mathrm{M}$ theophylline for $180 \mathrm{~min}$ and loaded with indo-1-AM during the last $30 \mathrm{~min}$. In these cells elevated protein kinase $\mathrm{A}$ activity ratios were sustained over the entire period. Addition of PAF similarly stimulated increases in $\left[\mathrm{Ca}^{2+}\right]_{\mathrm{i}}$ which were little or no different from control cells.

\section{Discussion}

PAF is a unique lipid mediator, with effects on many cell types and tissues, and likely plays a role in a number of diseases, including asthma, allergies, and anaphylaxis (24). Because of its role in activation of different cells, delineation of the

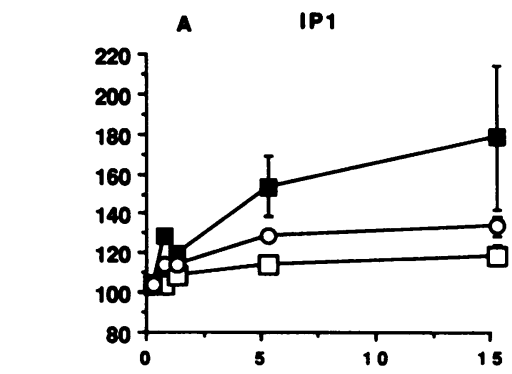

Figure 4. PAF-induced liberation of inositol phosphates is inhibited by the toxins. $\mathrm{HSCE}^{-}$

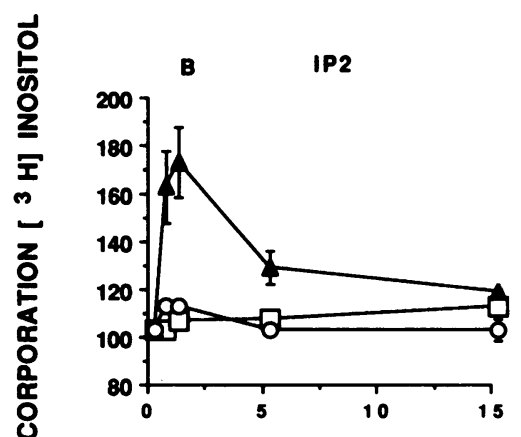

cells were prepared as described for the extraction and separation of $\mathrm{PIP}_{2}$ breakdown products. The figure demonstrates the liberation of $\mathrm{IP}_{1}(\boldsymbol{\bullet}), \mathrm{IP}_{\mathbf{2}}(\Delta)$, and $\mathrm{IP}_{3}$ $(\bullet)$ after stimulation of the cells with PAF $\left(10^{-7}\right.$ $M)$. The open symbols represent results from cells pretreated for $3 \mathrm{~h}$ with PT $(\square, 100 \mathrm{ng} / \mathrm{ml})$ or CT $(0,100 \mathrm{ng} / \mathrm{ml})$. Identical results were obtained with LA350 cells. The figure represents the means \pm SEM of three separate experiments. Control values: $\mathrm{IP}_{1}, 1,140 \pm 170 \mathrm{cpm}$ $\mathrm{IP}_{2}, 580 \pm 60 ; \mathrm{IP}_{3}$, $340 \pm 40 \mathrm{cpm}$. Preincubation for $3 \mathrm{~h}$ with PT and CT increased control values by $10-12 \%$.

method of signal transduction is important for development of pharmacologic agents to counteract its effects. We have previously reported that PAF stimulates B lymphoblasts, leading to elevations of $\left[\mathrm{Ca}^{2+}\right]_{\mathrm{i}}$ and liberation of inositol phosphates $(6)$. However, definition of the precise signaling pathway through the PAF receptor has not been easy to accomplish in different cell types and interspecies variability has been observed (1). On human cells, two distinct subtypes of PAF receptors have been postulated (5). Human platelets have been demonstrated to have PAF receptors that are insensitive to PT and CT, and have a differential dose responsiveness to PAF antagonists when compared to other tissues (25). Human neutrophils, in contrast, are sensitive to both PT and CT $(1,5)$, as no PAFstimulated GTPase activity was found following incubation with the toxins (5).

The ability of PAF to cause biochemical changes after receptor ligand interaction in B lymphocytes provides an opportunity for comparative studies of signal transduction pathways in these cells. This is due to the availability of specific antagonists to PAF, and, more importantly, because of the ability to contrast with signaling through the sIgM receptor (6). We therefore undertook to delineate the sensitivity of the PAF receptor to preincubation with PT and CT, both of which have been demonstrated to inhibit PAF-mediated signaling in human hematopoietic cells and modulate the function of GTP binding proteins. These studies were performed with the IgG- 
A

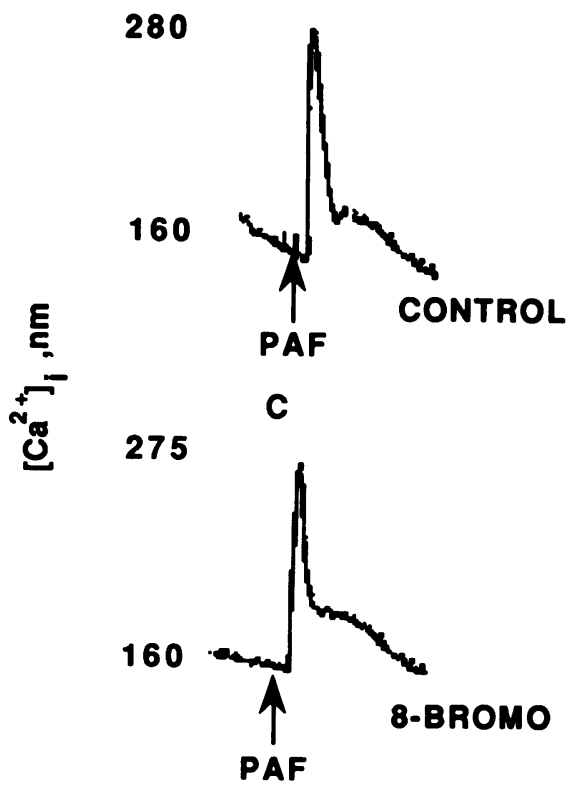

B

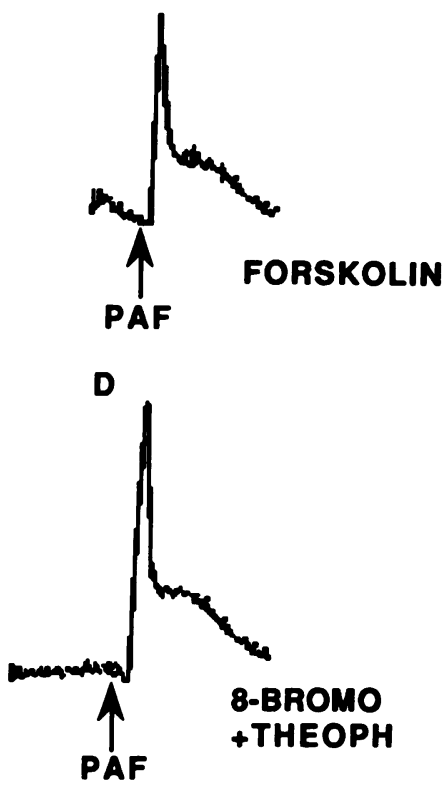

Figure 5. The effects of PT and CT are not due to elevation of cAMP. Following indo-1 loading, HSCE $^{-}$ cells were stimulated with $\operatorname{PAF}\left(10^{-7} \mathrm{M}\right)$ after preincubation for 30 min with: $(A)$ medium alone; $(B)$ forskolin $\left(10^{-4} \mathrm{M}\right)$; $(C)$ 8-bromo-cAMP $\left(10^{-4} \mathrm{M}\right)$; (D) 8-bromo-cAMP $\left(10^{-4} \mathrm{M}\right)$ plus theophylline $\left(10^{-4} \mathrm{M}\right)$. The figure demonstrates tracings representative of one of four different experiments. secreting B-lymphoblastoid cell line $\mathrm{HSCE}^{-}$and the IgM-secreting LA350 cell line; the latter cell line, which expresses sIgM, responds to both PAF and anti-IgM stimulation $(6,26)$.

The PAF receptor on B-lymphoblastoid cell lines appears to be similar to human polymorphonuclear leukocytes, that is, sensitive to both PT and CT (5). The elevation of intracellular $\mathrm{Ca}^{2+}$ levels triggered by the addition of PAF in the two B-lymphoblastoid cell lines was inhibited after a 3-h preincubation of the cells with either PT or CT. This inhibition was both timeand dose-dependent as well as specific, as it did not alter $\mathrm{Ca}^{2+}$ mobilization induced by anti-IgM stimulation of LA350 cells (Fig. 1). Further, the inactive B-subunits of both CT and PT did not affect the $\mathrm{Ca}^{2+}$ response induced by $\operatorname{PAF}(16,27,28)$. Monitoring cells suspended in $\mathrm{Ca}^{2+}$-free medium revealed that the toxins inhibited both phases of the $\mathrm{Ca}^{2+}$ response, the initial transient peak due to the release of internal $\mathrm{Ca}^{2+}$ stores, and the plateau phase, primarily representing transmembrane uptake of $\mathrm{Ca}^{2+}$. In the presence of lower concentrations of the

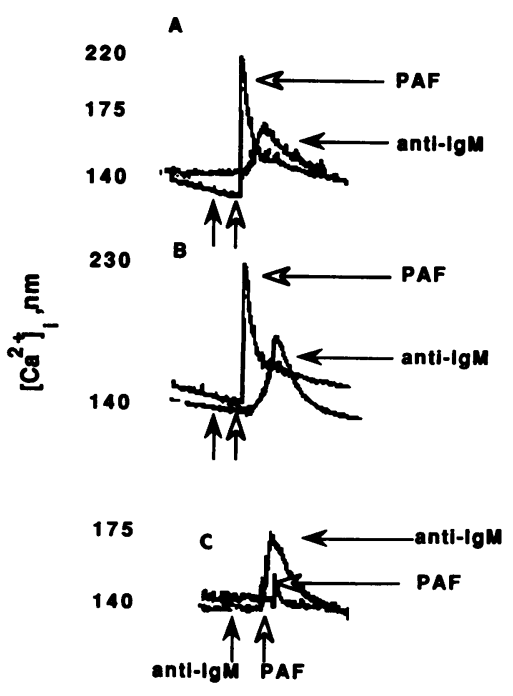

Figure 6. Effect of forskolin and PT on PAF and anti-IgM mediated increases in $\left[\mathrm{Ca}^{2+}\right]_{\mathrm{i}}$. After indo-1 loading of LA350 cells, $(A)$ medium, $(B)$ forskolin $\left(10^{-4} \mathrm{M}\right)$, or $(C)$ PT $(100 \mathrm{ng} / \mathrm{ml})$ was added. $\operatorname{PAF}\left(10^{-7} \mathrm{M}\right)$ or anti$\operatorname{IgM}(10 \mu \mathrm{g} / \mathrm{ml})$ was then added 30 min later where indicated by the arrows below each tracing and $\left[\mathrm{Ca}^{2+}\right]_{i}$ monitored. Representative of one of three similar experiments. toxins, some dissociation of their effects could be observed, suggesting that transmembrane uptake of $\mathrm{Ca}^{2+}$ was the more sensitive component of the response. Since release of $\mathrm{Ca}^{2+}$ from internal stores may be mediated by the release of $\mathrm{IP}_{3}$ from membrane phospholipids (29), we examined whether IP metabolism was inhibited by PT and CT as well. We showed that $100 \mathrm{ng} / \mathrm{ml} \mathrm{PT}$ and CT markedly attenuated the hydrolysis of $\mathrm{PIP}_{2}$ to $\mathrm{IP}_{1}, \mathrm{IP}_{2}$, and $\mathrm{IP}_{3}$.

PT and CT both bind to $\alpha$ subunits of GTP-binding proteins (30). CT ADP-ribosylates $\alpha_{\mathrm{s}}$ residues causing a marked increase in intracellular levels of cAMP. PT is known to ADPribosylate $\alpha_{\mathrm{i}}$ and $\alpha_{\mathrm{o}}$ in GTP-binding proteins and transducins (31). As a result, PT inhibits adenylate cyclase, with an opposite effect on cAMP compared to CT. PT modifies the GTPbinding subunits by binding to a cystine residue that is highly conserved in the $G_{i / o}$ and transducin subtypes. In contrast, the CT ADP-ribose acceptor site is an arginine residue found not only in $\alpha_{s}$ subunits, but also in $\alpha_{i}, \alpha_{o}$, and transducins. Therefore, known PT-sensitive G-protein subunits or cytoskeletal elements have been demonstrated to be ADP-ribosylated by CT, such as in retinal rod membranes (32), neuroblastoma cell lines (31), and HL-60 cells (33). The effects of CT in these cases are independent of cAMP, and are distinctly like PT-mediated events. This mechanism has been suggested by Imboden et al. (27), who demonstrated that CT inhibited both elevations of $\left[\mathrm{Ca}^{2+}\right]_{i}$ and $\mathrm{PIP}_{2}$ metabolism independently of cAMP elevation in anti-CD3 stimulated Jurkat cells, and recently by Gouy et al. (28) in a similar Jurkat system. Bacon and Camp have made similar observations regarding IL-8-mediated enhancement of lymphocyte migration (34). Therefore, the observation that PAF-mediated elevations in $\left[\mathrm{Ca}^{2+}\right]_{i}$ and $\mathrm{IP}_{3}$ are sensitive to both PT and CT can be interpreted as evidence that the PAF receptor is coupled to a GTP-binding protein that is PT sensitive, and can be ribosylated by CT. This argument is strengthened by the observations that the incubation of the cells with forskolin or 8-bromo cAMP (with or without the phosphodiesterase inhibitor theophylline) for time periods of 30-180 min had little effect on PAF-induced changes in 
$\left[\mathrm{Ca}^{2+}\right]_{i}$ (Figs. 5 and 6 ). This lack of effect of cyclic AMP analogues and forskolin in inhibiting the effects of PAF argues that CT binding to $\alpha_{s}$ and elevation of intracellular CAMP is not the explanation for its effectiveness in inhibiting PAF-induced $\left[\mathrm{Ca}^{2+}\right]_{\mathrm{i}}$ elevations and IP breakdown. Exactly what GTP-binding proteins are found in these lymphoblastoid cell lines is currently under study, to examine the specificity of the binding sites for PT and CT.

In comparing the elevations in $\left[\mathrm{Ca}^{2+}\right]_{i}$ by PAF and antiIgM in cell lines with both receptors, we observed that there was no heterologous desensitization between these two ligands (6). The phenomenon of homologous or heterologous desensitization was first described in the $\beta$-adrenergic system (35). Desensitization, although not well understood, is likely due to the uncoupling of receptors secondary to distal biochemical events such as the elevation of CAMP and protein phosphorylation after receptor-ligand interaction. In B-lymphocyte cell lines, $\mathrm{Ca}^{2+}$ signaling through sIgM can be desensitized after stimulation with anti-IgD (36), anti-CD19 (36), and antiCD21 (37). However, since PAF did not desensitize the $\left[\mathrm{Ca}^{2+}\right]_{\mathrm{i}}$ response to cross-linking of slgM, this implied that PAF and anti-IgM may have different signaling pathways.

There have been attempts to link anti-IgM signaling to GTP-binding proteins, but these have been limited by the inability to block early signal transduction events with either PT or CT. Anastassiou et al. (14) showed that while CT could block B-cell proliferation induced by anti-IgM antibodies, there was no effect of CT (or forskolin) on anti-IgM-induced elevation of $\left[\mathrm{Ca}^{2+}\right]_{\mathrm{i}}$. Harnett and Klaus (9) demonstrated the hydrolysis of inositol phosphates by anti-IgM and anti-IgD in murine B lymphocytes. Stimulation of permeabilized B cells by GTP $\gamma$-S was augmented by the addition of an anti-IgM or antiIgD antibody, suggesting the link to a GTP-binding protein. The inability of these responses to be inhibited by PT or CT forced the authors to conclude that GTP-binding proteins coupled to the sIgM receptor are of an unidentified type. There is also evidence that signaling via SIgM may be through PLC- $\gamma_{1}$. This was demonstrated by Carter et al. (38) both indirectly, by the suppression of stimulated increases in $\left[\mathrm{Ca}^{2+}\right]_{\mathrm{i}}$ and IP generation after incubation of the cells together with tyrphostins or herbimycin, and directly, by immunoprecipitation of activated PLC $\gamma_{1}$ after anti-IgM stimulation. In contrast to PAF-mediated increases in $\left[\mathrm{Ca}^{2+}\right]_{i}$, PT and CT had no effect on the increases in $\left[\mathrm{Ca}^{2+}\right]_{\mathrm{i}}$ stimulated by anti-IgM antibody in this study. Therefore the GTP-binding protein involved in coupling PLC- $\gamma_{1}$ to the mIg complex is likely different from the binding protein that couples the PAF receptor to PLC. Recently, Honda et al. cloned a PAF receptor gene from guinea pig lung into xenopus oocytes (39) and from human peripheral leukocytes (40). Their analysis of the gene for the receptor shows homology with other members of the G-protein-coupled receptor family, supporting this hypothesis.

In summary, we have demonstrated that PAF-induced increases in intracellular $\mathrm{Ca}^{2+}$ and $\mathrm{PIP}_{2}$ hydrolysis are sensitive to both pertussis and cholera toxins. Therefore, the PAF receptor found in human B-lymphoblastoid cell lines is most likely coupled to its receptor via a GTP-binding protein. It appears that this receptor has characteristics similar to those expressed by human polymorphonuclear leukocytes, and indicates that the PAF receptor on human B cells may also belong to the GTPbinding protein superfamily.

\section{Acknowledgments}

We thank Drs. Joe Spahn and David Riches for advice on the studies of inositol phosphate metabolism, Dr. Gary Johnson for helpful discussion, and Charlene Barnhorst and Jane Watkins for preparation of this manuscript.

This work was supported by grants AI-26490 and AI-29704 from the National Institutes of Health (E. W. Gelfand). B. D. Mazer is a Fellow of the Medical Research Council of Canada. E. W. Gelfand is a Scholar of the Raymond and Beverly Sackler Foundation.

\section{References}

1. Hwang, S. B. 1990. Specific receptors of platelet-activating factor, receptor heterogeneity, and signal transduction mechanisms. J. Lipid Mediators. 2:123158.

2. Lad, P. M., C. V. Olsen, I. S. Grewel, and S. J. Scott. 1985. A pertussis toxin sensitive GTP binding protein in the human neutrophil regulates multiple receptors, calcium mobilization, and lectin-induced capping. Proc. Natl. Acad. Sci. USA. 82:8643-8647.

3. Matsumoto, T., T.F. P. Molski, Y. Kansho, E. L. Becker, and R. I. Sha'afi. 1987. G-protein dissociation, GTP-GDP exchange, and GTPase activity in control and PMA treated neutrophils stimulated by fmet-leu-phe. Biochem. Biophys. Res. Commun. 143:489-498.

4. Homma, H., and D. J. Hanahan. 1988. Attenuation of platelet-activating factor (PAF)-induced stimulation of rabbit platelet GTPase by phorbol ester, dibutyryl cAMP, and desensitization: concomitant effects on PAF receptor binding characteristics. Arch. Biochem. Biophys. 262:32-39.

5. Hwang, S.-B. 1988. Identification of a second putative receptor of plateletactivating factor from human polymorphonuclear leukocytes. J. Biol. Chem. 263:3225-3233.

6. Mazer, B., J. Domenico, H. Sawami, and E. W. Gelfand. 1991. Platelet-activating factor induces an increase in intracellular calcium and expression of regulatory genes in human B lymphoblastoid cells. J. Immunol. 146:1914-1920.

7. DeFranco, A. L., D. M. Page, J. H. Blum, and M. R. Gold. 1989. Signal transduction by the antigen receptor of B lymphocytes. Cold Spring Harbor Symposia on Quantitative Biology, Vol. LIV. Cold Spring Harbor Laboratory Press, Cold Spring Harbor, NY. pp. 733-740.

8. Shearer, W. T., E. B. Gilliam, H. M. Rosenblatt, and F. M. Orson. 1988. I. Anti- $\mu$ antibody stimulates the phosphatidylinositol cycle and immunoglobulin secretion in a human lymphoblastoid B-cell line, LA350. Cell. Immunol. 111:296-315.

9. Harnett, M. M., and G. G. B. Klaus. 1988. G protein coupling of antigen receptor-stimulated polyphosphoinositide hydrolysis in B cells. J. Immunol. 140:3135-3139.

10. Mazer, B., K. L. Clay, H. Renz, and E. W. Gelfand. 1990. Platelet-activating factor enhances Ig production in B lymphoblastoid cell lines. J. Immunol. 145:2602-2607.

11. MacDougall, S. L., S. Grinstein, and E. W. Gelfand. 1988. Activation of $\mathrm{Ca}^{2+}$-dependent $\mathrm{K}^{+}$channels in human $\mathrm{B}$ lymphocytes by anti-immunoglobulin. J. Clin. Invest. 81:449-454.

12. Berridge, M. J., R. M. C. Dawson, P. C. Downes, J. P. Heslop, and R. F. Irvine. 1983. Changes in the levels of inositol phosphates after agonist-dependent hydrolysis of membrane phosphoinositols. Biochem. J. 212:473-482.

13. MacDougall, S. L., S. Grinstein, and E. W. Gelfand. 1988. Detection of ligand activated conductive $\mathrm{Ca}^{2+}$ channels in human $\mathrm{B}$ lymphocytes. Cell. 54:229-234

14. Anastassiou, E. D., H. Yamada, M. L. Francis, J. J. Mond, and G. C. Tsokos. 1990. Effects of cholera toxin on human B cells. Cholera toxin induces B cell surface DR expression while it inhibits anti- $\mu$ antibody-induced cell proliferation. J. Immunol. 145:2375-2380.

15. Warner, G. L., S. Davies, and D. W. Scott. 1989. Cholera toxin sensitive and insensitive signalling via surface Ig. J. Immunol. 143:458-463.

16. Rogers, R. S., S. J. Corey, and P. M. Rosoff. 1990. Identification of a 43-kilodalton human $T$ lymphocytes membrane protein as a receptor for pertussis toxin. J. Immunol. 145:678-683.

17. Birnbaumer, L., J. Abramowitz, A. Yatani, K. Okabe, R. Mattera, R. Graf, J. Sanford, J. Codina, and A. M. Brown. 1990. Roles of G proteins in coupling of receptor to ionic channels and other effector systems. Crit. Rev. Biochem. Mol. Biol. 25:225-244.

18. Shukla, S. D., W. J. Morrison, and A. Dhar. 1989. Desensitization of platelet-activating factor-stimulated protein phosphorylation in platelets. $\mathrm{Mol}$. Pharmacol. 35:409-413.

19. Grandison, L. 1990. Platelet activating factor induces inositol phosphate accumulation in cultures of rat and bovine anterior pituitary cells. Endocrinology. 127:1786-1791 
20. Francis, M. L., J. Moss, T. A. Fitz, and J. J. Mond. cAMP-independent effects of cholera toxin on B cell activation. 1. A possible role for cell surface ganglioside $\mathrm{G}_{\mathrm{M} 1}$ in $\mathrm{B}$ cell activation. J. Immunol. 145:3162-3169.

21. Ransom, J. T., and J. C. Cambier. 1986. B cell activation. VII. Independent and synergistic effects of mobilized calcium and diacylglycerol on membrane potential and I-A expression. J. Immunol. 136:66-72.

22. Dugas, B., J. F. Delfraissy, A. Calenda, M. Feuchmaur, C. Wallon, M.-T. Rannous, and P. Galanaud. 1988. Activation and infection of B cells by EpsteinBarr virus. Role of calcium mobilization and of protein kinase $C$ translocation. $J$. Immunol. 141:4344-4351.

23. Lingk, D. S., M. A. Chan, and E. W. Gelfand. 1990. Increased cyclic adenosine monophosphate levels block progression but not initiation of human $\mathrm{T}$ cell proliferation. J. Immunol. 145:449-455.

24. Barnes, P. J. 1989. New concepts in the pathogenesis of bronchial hyperresponsiveness and asthma. J. Allergy Clin. Immunol. 83:1013-1026.

25. Lambrecht, G., and M. Parnham. 1986. Kadsurenone distinguishes between different platelet activating factor receptor subtypes on macrophages and polymorphonuclear leukocytes. Br. J. Pharmacol. 87:279-287.

26. Schulam, P. G., G. Putcha, J. Franklin-Johnson, and W. T. Shearer. 1990. Evidence for a platelet activating factor receptor on human lymphoblastoid B cells: activation of the phosphoinositol cycle and induction of calcium mobilization. Biochem. Biophys. Res. Commun. 166:1047-1052.

27. Imboden, J. B., D. Shoback, G. Pattison, and J. D. Stobo. 1986. Cholera toxin inhibits the T-cell antigen receptor mediated increases in inositol trisphosphate and cytoplasmic free calcium. Proc. Natl. Acad. Sci. USA. 83:5673-5677.

28. Gouy, H., D. Cefai, S. B. Christensen, P. Debre, and G. Bismuth. 1991 Cyclic AMP- and inositol phosphate-independent inhibition of $\mathrm{Ca}^{2+}$ influx by cholera toxin in CD3 stimulated Jurkat T cells. J. Immunol. 147:757-766.

29. Berridge, M. J., and R. F. Irvine. 1989. Inositol phosphates and cell signaling. Nature (Lond.). 341:197-205.

30. Birnbaumer, L. 1990. Transduction of receptor signal into modulation of effector activity by G proteins: the first 20 years or so . . . FASEB (Fed. Am. Soc. Exp. Biol.) J. 4:3068-3078.

31. Klinz, F. -J. and T. Costa. 1989. Cholera toxin ADP-ribosylates the recep- tor coupled form of pertussis toxin-sensitive G-proteins. Biochem. Biophys. Res. Commun. 165:554-560.

32. Abood, M. E., J. B. Hurley, M. -C. Paponne, H. R. Bourne, and C. Stryer. 1982. Functional homology between signal-coupling proteins. Cholera toxin inactivates the GTPase activity of transducin. J. Biol. Chem. 257:10540-10543.

33. Iiri, T., M. Tokhin, N. Morishima, Y. Ohaka, M. Ui, and T. Katada. 1989. Chemotactic peptide-receptor supported ADP-ribosylation of a pertussis toxin substrate GTP-binding protein by cholera toxin in neutrophil-type HL-60 cells. J. Biol. Chem. 264:21394-21400.

34. Bacon, K. B., and R. D. R. Camp. 1990. Interleukin-8 induced in vitro human lymphocyte migration is inhibited by cholera and pertussis toxins and inhibitors of protein kinase C. Biochem. Biophys. Res. Commun. 169:10991104.

35. Sibley, D. R., and R. J. Lef kowitz. 1985. Molecular mechanisms of receptor desensitization using the $\beta$-adrenergic receptor coupled adenylate cyclase system as a model. Nature (Lond.). 317:124-131.

36. Cambier, J., Z. Z. Chen, J. Pasternak, J. Ransom, V. Sandoval, and H. Pickles. 1988. Ligand-induced desensitization of B-cell membrane immunoglobulin-mediated $\mathrm{Ca}^{2+}$-mobilization and protein kinase $\mathrm{C}$ translocation. Proc. Natl. Acad. Sci. USA. 85:6493-6497.

37. Rijkers, G. T., A. W. Griffioen, B. J. M. Zegers, and J. C. Cambier. 1990. Ligation of membrane immunoglobulin leads to inactivation of the signal-transducing ability of membrane immunoglobulin, CD19, CD21, and B-cell gp95. Proc. Natl. Acad. Sci. USA. 87:8766-8770.

38. Carter, R. H., D. J. Park, S. G. Rhee, and D. T. Fearon. 1991. Tyrosine phosphorylation of phospholipase $\mathrm{C}$ induced by membrane immunoglobulin in B lymphocytes. Proc. Natl. Acad. Sci. USA. 88:2745-2749.

39. Honda, Z. -I., M. Nakamura, I. Miki, M. Minami, T. Watanabe, Y. Seyama, H. Okado, H. Toh, K. Ito, T. Miyamoto, and T. Shimzu. 1991. Cloning by functional expression of platelet-activating factor receptor from guinea-pig lung. Nature (Lond.). 349:342-346.

40. Nakamura, M., Z. Honda, T. Izumi, C. Sakanaka, H. Mutoh, M. Minami, H. Bito, Y. Seyama, T. Matsumoto, M. Noma, and T. Shimizu. 1991. Molecular cloning and expression of platelet-activating factor receptor from human leukocytes. J. Biol. Chem. 266:20400-20405. 